\title{
AIR FLOW HUMIDIFICATION FOR AIR-ASSISTED BOOM SPRAYER
}

\section{WILSON M. STANISLAVSKI ${ }^{1}$, ULISSES R. ANTUNIASSI ${ }^{2}$, RODOLFO G. CHECHETTO ${ }^{3}$}

\begin{abstract}
The air-assisted ground spray is fairly widespread. However, due to the unpredictable weather conditions, the operational efficiency is impaired by stops on grounds of low humidity and high temperatures. The aim of this work was to assess an air humidification method and evaluate its impact on temperature and air humidity for the air curtain of the air-assisted sprayer. With respect to relative air humidity, it has increased in $6.59 \%$, being the maximum change when inserting $1.92 \mathrm{~L} \mathrm{~min}^{-1}$. So, it is concluded that the pipeline humidification might significantly reduce temperature and enhance air humidity. The treatments performed in this study consisted of a varied flow of a humidity device, related to weather conditions. Temperature and relative air humidity were measured at $1.0 \mathrm{~m}$ height from right to left of middle point of the machine, corresponding to the end of the spray boom, in the middle and end of right spray boom. The readings were also performed at three different distances from the end of the pipeline and at 0.25 and $0.50 \mathrm{~m}$ from that to the soil. The results show that $0.48 \mathrm{~L} \mathrm{~min}^{-1}$ in the humidification system has promoted a better efficiency in reducing air-temperature, on average $2.52{ }^{\circ} \mathrm{C}$ when compared to the non-humidified one.
\end{abstract}

KEY-WORDS: Weather Conditions; Air-assisted Boom; Application Technology.

\section{UMIDIFICAÇÃO DO FLUXO DE AR EM PULVERIZADOR DE BARRAS COM ASSISTENNCIA DE AR}

RESUMO: A aplicação terrestre com assistência de ar é bastante difundida. Entretanto, devido às variações climáticas, o rendimento operacional é prejudicado pelas paradas devido à baixa umidade relativa do ar e a altas temperaturas. O objetivo do trabalho foi pesquisar uma forma de umidificar o ar e avaliar a interferência desta umidificação na temperatura e umidade relativa do ar na cortina de vento em pulverizador com assistência de ar. Os tratamentos corresponderam a diferentes vazões de um dispositivo de umidificação, relacionados às condições climáticas. Foram realizadas leituras de temperatura e umidade relativa a 1,0 m para a direita e para a esquerda, do centro da máquina, correspondendo às extremidades da barra central, no centro e na extremidade da barra direita. As leituras foram realizadas, também, em três distâncias na saída da canaleta, sendo uma na saída do ar da canaleta e a 0,25 e $0,50 \mathrm{~m}$ da mesma, em sentido ao solo. Os resultados mostraram que a vazão de $0,48 \mathrm{~L} \mathrm{~min}^{-1}$ no sistema de umidificação proporcionou melhor eficiência em relação à redução da temperatura do ar, apresentando redução média de $2,52{ }^{\circ} \mathrm{C}$ comparado à barra assistida a ar sem umidificação. Já a umidade relativa do ar aumentou em $6,59 \%$, sendo esta a alteração máxima da umidificação injetando $1,92 \mathrm{~L} \mathrm{~min}^{-1}$. Conclui-se, assim, que a umidificação no duto de ar reduz a temperatura e aumenta a umidade relativa do ar de maneira significativa.

PALAVRAS-CHAVE: condições climáticas, barra assistida a ar, tecnologia de aplicação.

\section{INTRODUCTION}

The great weather changes occurred during spraying affect operational efficiency due to stops on grounds of unfavorable climatic conditions as low humidity, high temperature, and winds. RUEDELL (2002) described that spraying has to be avoided when temperature is below $10{ }^{\circ} \mathrm{C}$ or above $35^{\circ} \mathrm{C}$, aiming to spray agrochemicals between 20 and $30^{\circ} \mathrm{C}$.

\footnotetext{
${ }^{1}$ Eng $^{\mathbf{o}}$ Agrônomo, Mestre em Agronomia, Depto. de Eng. Rural, FCA-UNESP/Botucatu-SP, wilsonmarcoss@hotmail.com ${ }^{2} E_{n}{ }^{\circ}$ Agrônomo, Prof. Titular, Departamento de Engenharia Rural, FCA-UNESP/Botucatu - SP, ulisses@ fca.unesp.br ${ }^{3}$ Eng $^{\circ}$ Agrônomo, doutorando, Departamento de Engenharia Rural, FCA-UNESP/Botucatu - SP, rgchechetto@hotmail.com Recebido pelo Conselho Editorial em: 4-3-2013 
According to RAETANO (2011), the air-assisted technology for boom sprayers came out in 1997 for the Brazilian industry. It is distinguished by being air pipelines formed by an air curtain of high speed air flow, which are emitted from two fans to the spray. That air curtain has the objective to speed up the vertical droplets, promoting na ideal penetration through the plants, better vertical spray distribution (RAETANO, 2011) and reduced drift (BAUER \& RAETANO, 2000; PRADO et al., 2010). Moreover, the air moves the plant leaves what may exposes their lower surfaces to an increased product amount than in conventional application; and the transversal air movement through the plant canopy enhance the deposition probability on the plant base (MATHEWS, 1992; CHRISTOVAM et al., 2010; NAVITSKI, 2010). The drift reduction concernment is linked to very fine and medium droplets due to spray during high temperature and low humidity times as seen in BALAN et al. (2008) research, which is also associated with spray and spray nozzles (CHECHETTO \& ANTUNIASSI, 2012). Being observed in high wind speed in the environment (CUNHA, 2008).

The use of air-assisted spray boom may reduce drift, as improve cover and deposition, depending on crop stage and leaf mass. As according to MATTEWS (1992), the speed that drop size decreases is faster in high temperatures a low relative humidity.

The air-assisted combined with spray angulation might improve the deposit level on abaxial surface, priory in lower part of plants, promoting a better disease control (RAETANO, 2011).

According RUEDELL (2002), among environmental factors, the relative air humidity most affects the pesticides action. In a pesticide application, droplets must range around $0.5 \mathrm{~m}$ to reach target, and along this route, droplets are influenced by environmental factors, such as air humidity that control their lifetime.

In general, research results comparing conventional and air-assited spray in their deposition show that the later has reduced drift for small droplet sprays and under unfavorable conditions, mainly when wind speed is higher than recommended. The technique improves the lower part deposition of big plants; however, small plants may not reach such results and also increase spray deposition on soil.

The goal of this research was to develop a system to increase air humidity in an air-assisted boom sprayer; and, evaluate its interference on temperature and relative humidity in the wind curtain during application.

\section{MATERIAL AND METHODS}

The sprayer trial was performed in the Agroforestry Machine and Tire Research Center (NEMPA), Rural Engineering Department, FCA - UNESP, Botucatu - SP, Brazil. The flow and nozzle angulation measurements of the humidifier system were performed in the Research Center of Máquinas Agrícolas Jacto S.A., Pompéia - SP, Brazil.

The five treatments performed in this work are shown in Table 1; being four spray water flow to humidify the air-flow and a control.

TABLE 1. Treatment description.

\begin{tabular}{|c|c|c|c|c|c|}
\hline Treatments & A (control) & B & $\mathrm{C}$ & $\mathrm{D}$ & $\mathrm{E}$ \\
\hline Number of nozzles & 0 & 12 & 6 & 3 & 1 \\
\hline Pressure (kPa) & - & 1034 & 1034 & 1034 & 1034 \\
\hline Total flow $\left(\mathrm{L} \min ^{-1}\right)$ & 0 & 1.92 & 0.96 & 0.48 & 0.16 \\
\hline
\end{tabular}

The applications were executed by a Falcon Vortex spray model, manufactured by Máquinas Agrícolas Jacto S.A. was used in the trial. This spray has $14 \mathrm{~m}$ booms, blower of 2,800 rpm fan speed, air volume of $32,000 \mathrm{~m}^{3} \mathrm{~h}^{-1}$, air curtain of $100 \mathrm{~km} \mathrm{~h}^{-1}$ speed, taking of force rotation of 540 rpm. 
Empty cone nozzles (Misting) were used in the humidification device of the spray air flow, manufactured by Arag Spray Jets. These nozzles are used to mist environment. A $1.034 \mathrm{kPa}$ pressure and droplets with volumetric median diameter of $69.75 \pm 7.47 \mu \mathrm{m}$.

Measurements of temperature and relative air humidity both for environment and air curtain were performed using a digital 485-1 model thermohygrometer by Dwyer Instruments Inc. The relative humidity sensor has range of 0 to $100 \%, \pm 2 \%$ accuracy, and $0.1 \%$ resolution. The temperature scale is $-30{ }^{\circ} \mathrm{C}$ to $85^{\circ} \mathrm{C}, \pm 0.5 \%$ accuracy, and $0.1{ }^{\circ} \mathrm{C}$ resolution.

In order to humidify air water was sprayed onto the air flow through humidifier pipe branch using the proper hydraulic circuit. The flow diverted from spray boom branches to the humidified branches in air duct. The water injection into the air duct was allowed by arranging the $145 \mathrm{~mm}$ diameter circular branches in duct center right after the fan, spraying in the air flow direction (Figure 1). The pressure was monitored by spraying command manometer.
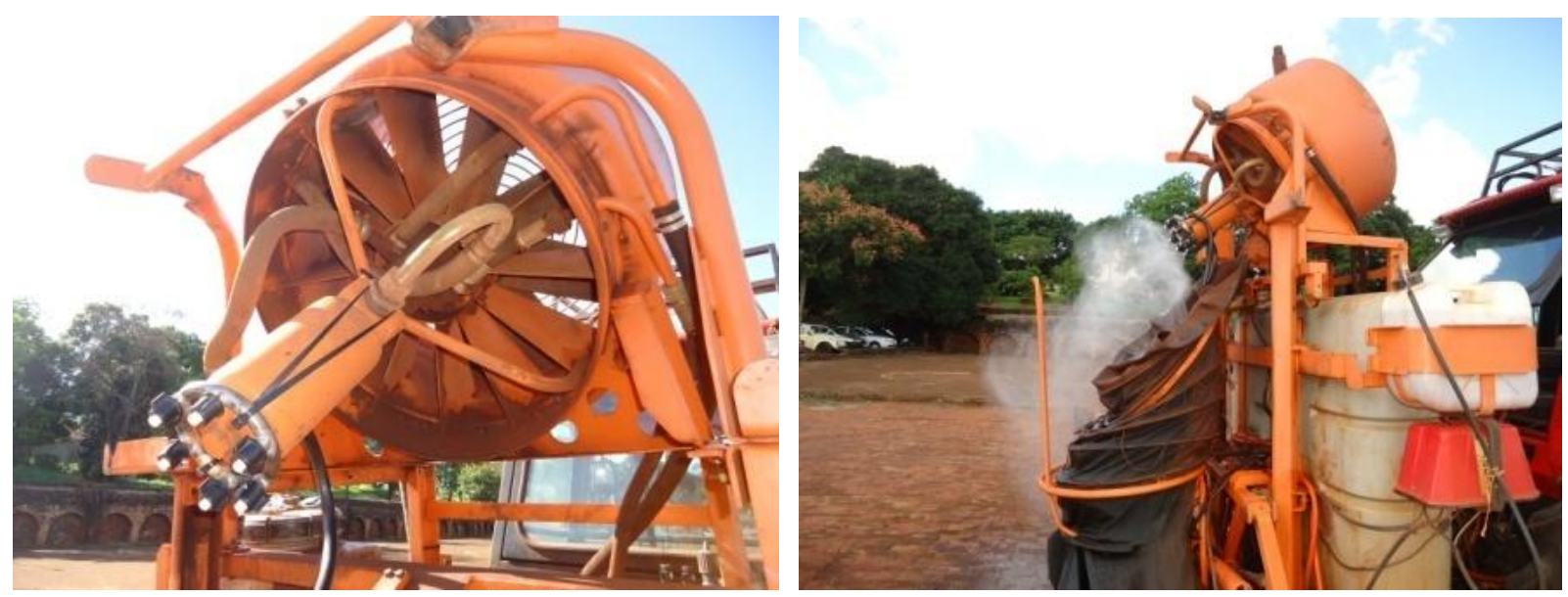

FIGURE 1. Humidifier branch arranged in air duct.

Temperature and humidity of the air curtain center formed by air-assisted boom system were measured at 0.0; 0.25; and $0.5 \mathrm{~m}$ from the pipeline end (FIGURE 2).

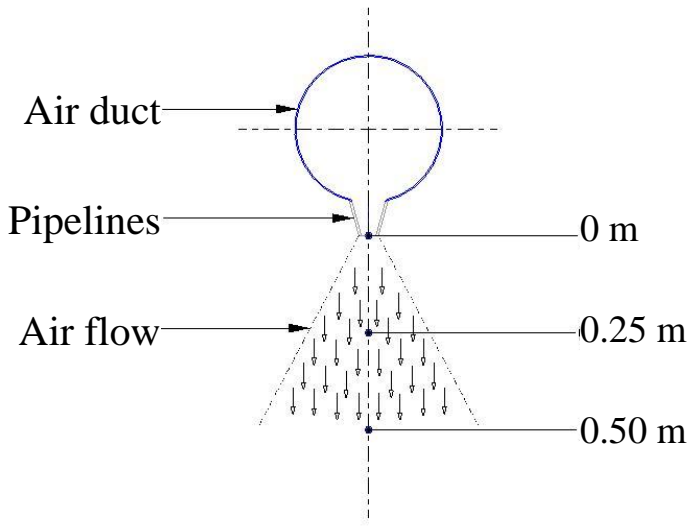

FIGURE 2. Distances of measurement points throughout the air curtain.

With respect to the boom length, one meter to the left and one meter to the right was measured from the machine center, corresponding to the right (I) and left (II) the spray boom end. From the right boom center to the right was also measured $3.25 \mathrm{~m}$ and $6.5 \mathrm{~m}$, III and IV points, respectively, as in Figure 3. Priory, it was attempted to locate the boom center, but ran out due to the droplet bump to the internal wall of the air duct, enabling measurement at this point. 


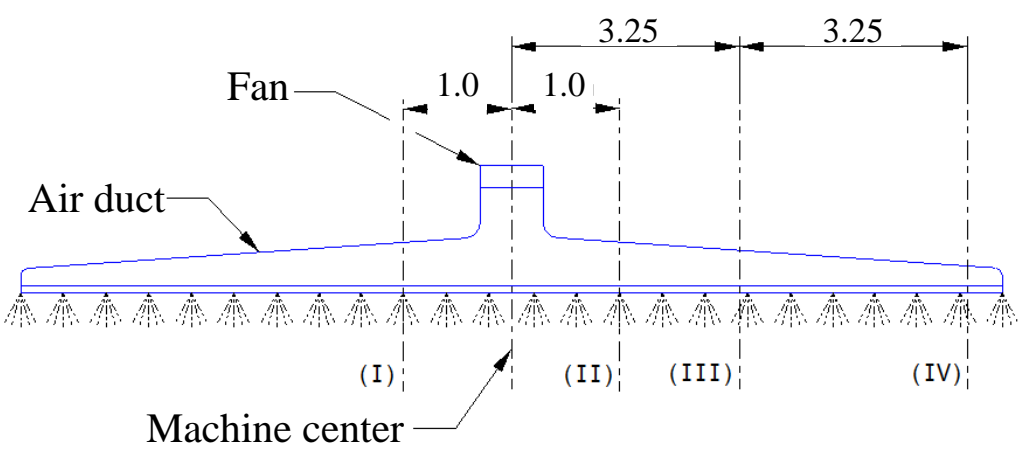

FIGURE 3. Measurement points throughout the boom length.

Brackets were applied to the spray boom to fix thermohygrometer as stated the points above, according to the boom length and distance from pipeline end, what always enable measurements at the same point. During trial, temperature varied from 26.7 to $28.1{ }^{\circ} \mathrm{C}$ and humidity from 53 to $59.1 \%$.

The results were expressed in the 95\% Confidence Interval for Mean Differences. Control and four flows were compared in the humidifier air system, in the four boom points, and in the three air exit distances. Four replications of temperature and humidity measurements were performed.

\section{RESULTS AND DISCUSSION}

There was a significant difference when temperature means were evaluated in the air curtain by $5 \%$ Confidence Interval related to the control, as in Figure 4. Among evaluated flows, there was significant difference merely for 0.48 and $0.16 \mathrm{~L} \mathrm{~min}^{-1}$, yet the other flows there were not.

When humidifying by using $0.48 \mathrm{~L} \mathrm{~min}^{-1}$ flow, there was a temperature fall in the air curtain, in na average of $2.52^{\circ} \mathrm{C}$ when compared to the air-assisted boom without humidification. The shortest temperature reduction was with $0.16 \mathrm{~L} \mathrm{~min}^{-1}$, reducing $1.07{ }^{\circ} \mathrm{C}$ in average temperature.

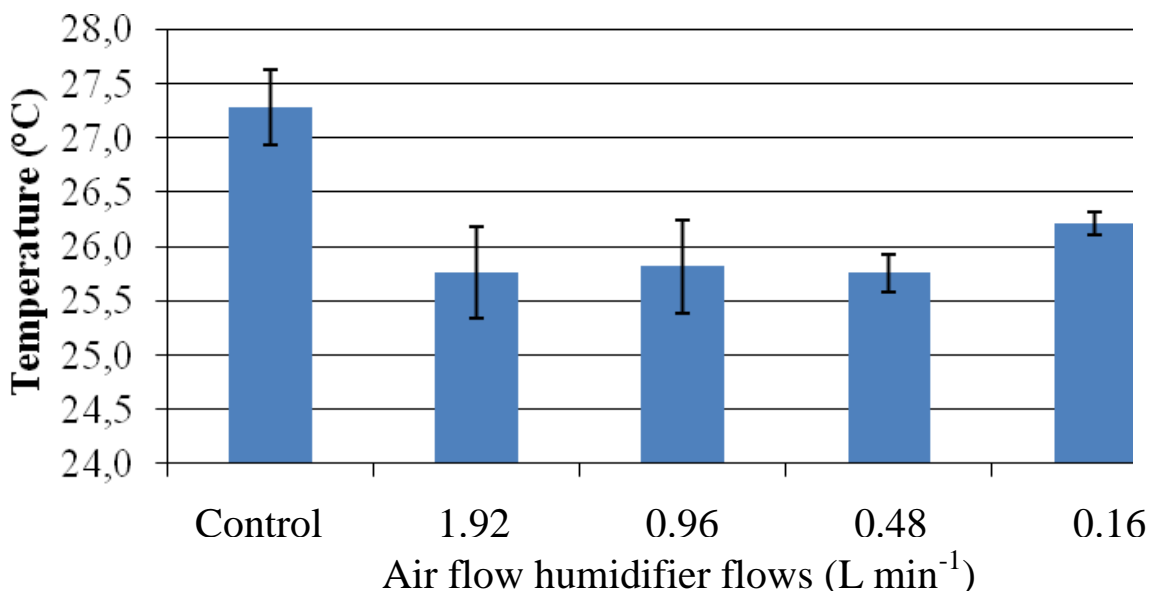

FIGURE 4. Average temperatures in the air curtain regarding to water humidifier flow.

YU et al. (2009) studying droplet diameters, air humidity, leaf structure, and pesticide formulation noted their influence in the droplet evapotranspiration on leaves surface, being crucial the technique establishment that enhance drop deposition. And also, XU et al. (2011) stated the time for a drop evaporation influence in its active ingredient absorption and translocation, so being directly influenced by weather conditions.

The right and left end of the central boom are same distance points from air-flow humidifier and also the closest ones, in this purpose they had temperature changes compared to the right boom end point. In the right and left central boom end there was a significant reduction in temperature by the humidification for all treatments. 


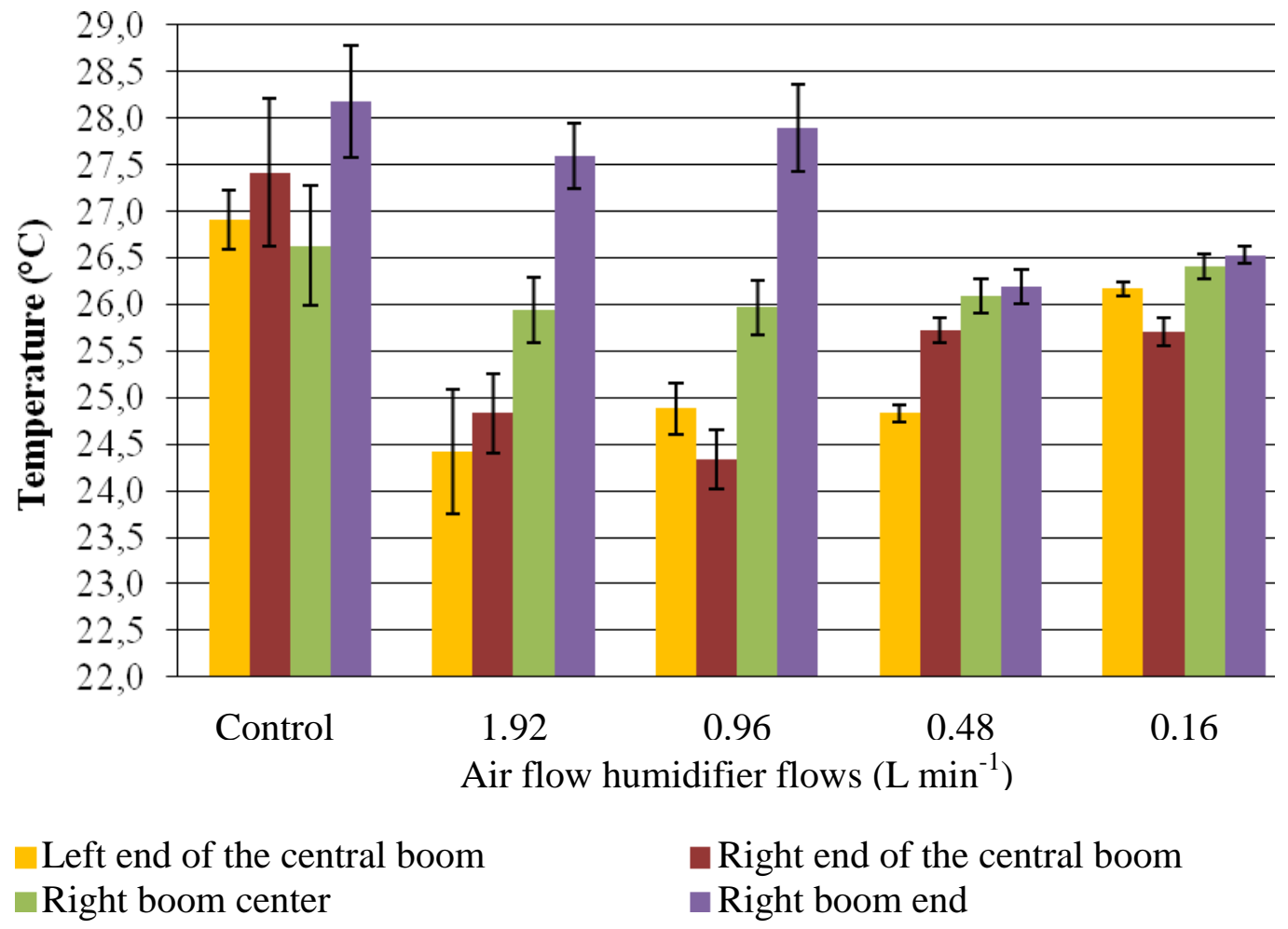

FIGURE 5. Air curtain temperature at various boom points.

At the left end of the center boom with air-flow humidification, only the $0.16 \mathrm{~L} \mathrm{~min}^{-1}$ flow got higher temperatures than the other three flows. The right end of the center boom with air-flow humidification, the 1.92 and $0.96 \mathrm{~L} \mathrm{~min}^{-1}$ had lower temperatures than the 0.48 and $0.16 \mathrm{~L} \mathrm{~min}^{-1}$ flow.

It is observed that there was no temperature difference in the curtain with and without air humidification in the right boom center. I was solely observed difference between 0.96 and $0.16 \mathrm{~L}$ $\min ^{-1}$ flows, and for $0.16 \mathrm{~L} \mathrm{~min}^{-1}$ the temperature was higher, but this difference was only $0.02{ }^{\circ} \mathrm{C}$. The air curtain temperatures at the end of the right boom had no difference with and without humidification of 1.92 and $0.96 \mathrm{~L} \mathrm{~min}^{-1}$. In the treatments with 0.48 and $0.16 \mathrm{~L} \mathrm{~min}^{-1}$ temperatures were lower than the other treatments and the control.

MATTHEWS (1992) have already reported the importance of knowing the spray amount that reaches the target, describing how the spray is influenced by the weather conditions; in this way, understanding these factors that may affect droplet movement are very important. RAMOS \& PIO (2008) describe that temperature; relative humidity; wind speed and direction are the most important conditions to check in pesticide application. As FAGGION \& ANTUNIASSI (2010), who reported the importance of knowing the spray nozzles in applications associated with ideal weather conditions.

As shown in Figure 6, it is not observed a significant difference in air curtain temperature in relation to the pipeline end distance. The air curtain temperature at the exit and at $250 \mathrm{~mm}$ from pipeline end was significantly reduced by humidifying the flow. Treatments conducted with certain flow humidification of 1.92 and $0.96 \mathrm{~L} \mathrm{~min}^{-1}$ presented the temperature at $500 \mathrm{~mm}$ significantly equal to control. In 0.48 and $0.16 \mathrm{~L} \mathrm{~min}^{-1}$ flows, the temperature was lower than control. In treatments with 1.92 and $0.96 \mathrm{~L} \mathrm{~min}^{-1}$, probably, overflows caused droplet coalescence making them larger, making it harder to follow the air flow through the ducts and change temperature in the wind curtain. 


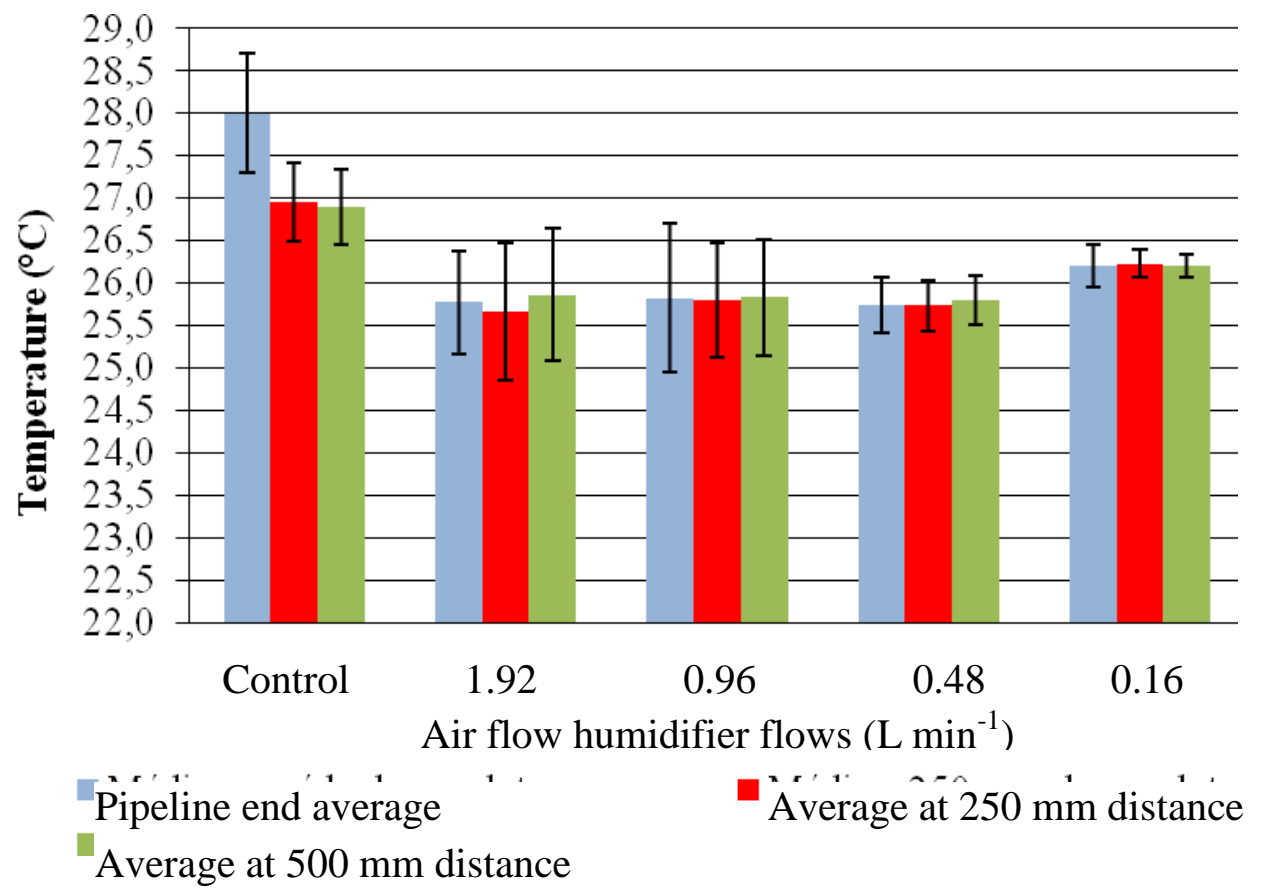

FIGURE 6. Average temperature graphics in the air curtain at three distances from pipeline end.

In BALAN et al. (2008) research is shown the temperature and relative humidity importance in the spray droplet deposition; thus, the higher the temperature at spray time and the lower the relative humidity, the lower the very thin drop deposition is. These results further reinforce the importance of mechanisms that seek for a better spray condition, mainly for fine droplets, which have a greater facility to not hit the target in adverse weather conditions.

The data exposed in FIGURE 7 allow us to state that there was a significant difference in the relative air humidity in humidifying the wind flow with all flow rates used. Among these flows, 0.96 and $0.48 \mathrm{~L} \mathrm{~min}^{-1}$ did not present significantly difference in treatments. The relative humidity increase average was increasing with increasing flow humidification. On average humidification raised the relative humidity in $6.59 \%$, which is the maximum alteration of humidification, which occurred at $1.92 \mathrm{~L} \mathrm{~min}^{-1}$.

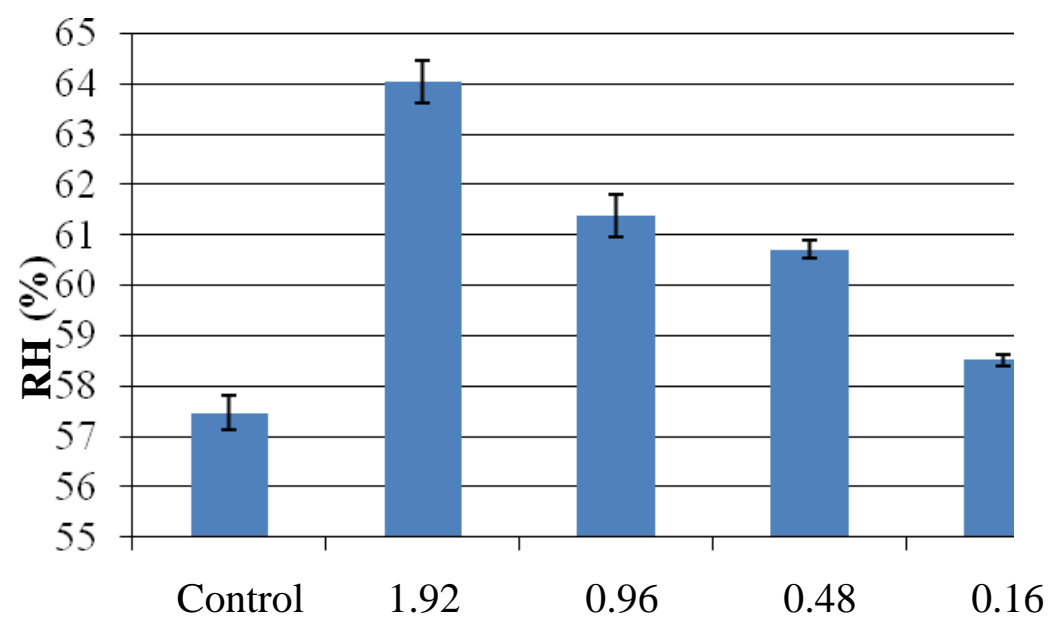

Air flow humidifier flows $\left(\mathrm{L} \mathrm{min}^{-1}\right)$

FIGURE 7. Average relative humidity graphic in the air curtain varying humidifier flow.

According to RAMSEY et al. (2006), the humidity has great effect on foliar pesticide application, primarily on the plant cuticle and also on droplet evaporation and deposition. RAMSEY et al. (2005) reported that many studies have been conducted to assess the environmental 
condition influence on sprays and in many of these studies, the relative humidity has a greater influence on application effectiveness than environmental temperature.

The left and right of the center boom ends are the points that have the same distance from the air-flow humidifier and are also closest to this point, so it had greater change in relative air humidity in the curtain when compared to the center and right boom end, it can be stated analyzing the Figure 8.

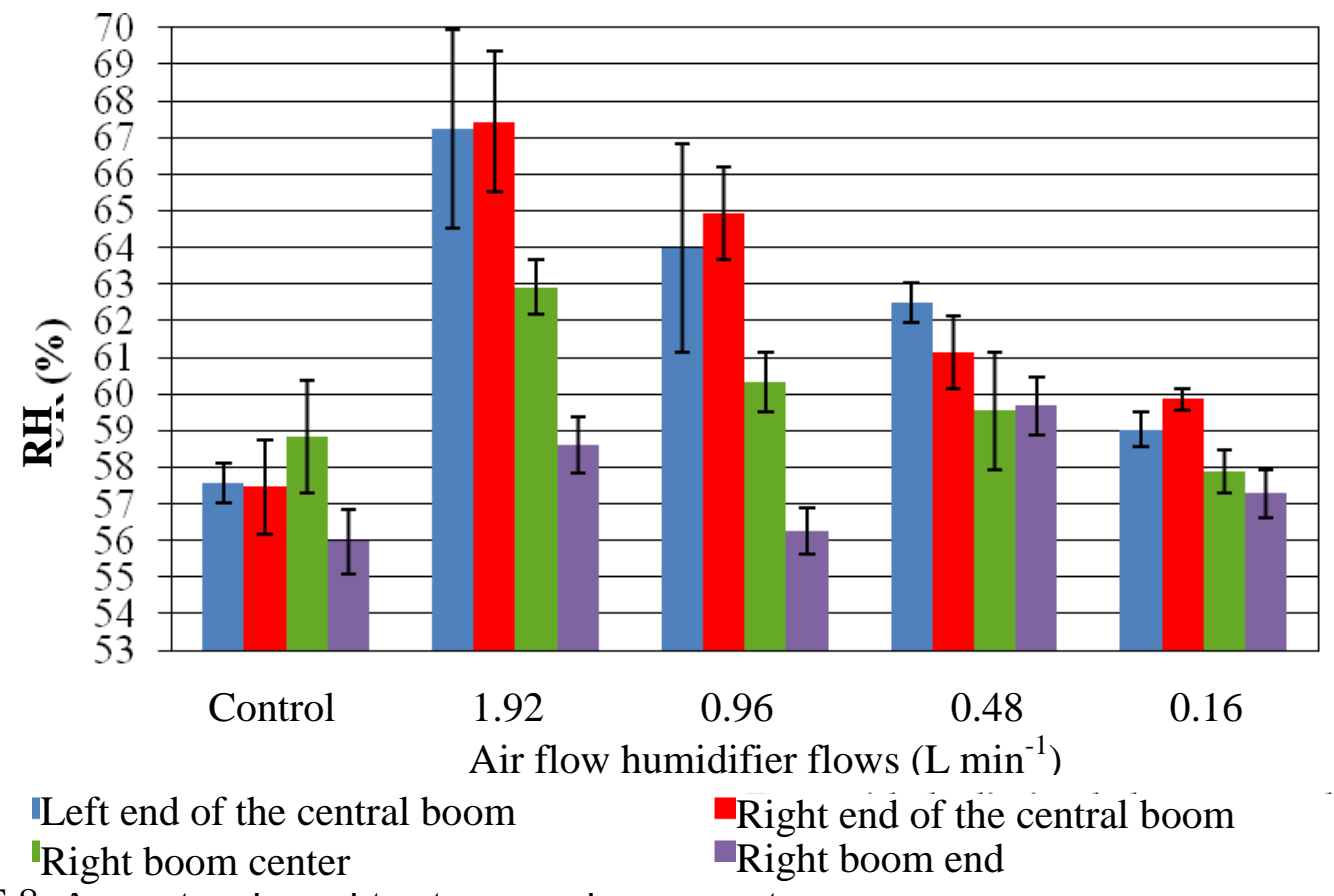

FIGURE 8. Air curtain humidity at varıous boom points.

Except for $0.16 \mathrm{~L} \mathrm{~min}^{-1}$ treatment, there was significant relative humidity increase in the air curtain to the right and left of central boom ends by using wind flow humidification system. In the central part, there was a difference in the $1.92 \mathrm{~L} \mathrm{~min}^{-1}$ treatment. For the right boom end, there was only a difference for 0.48 and $1.92 \mathrm{Lmin}^{-1}$ treatments.

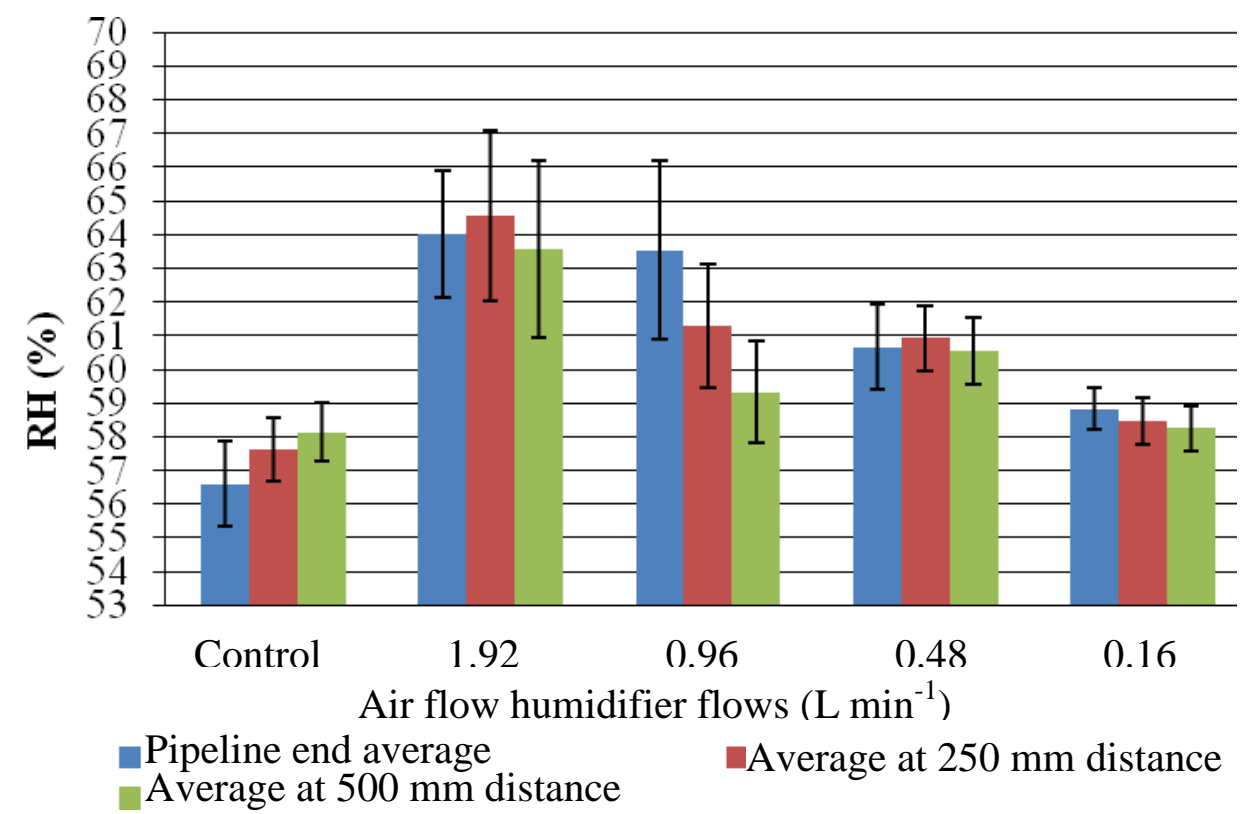

FIGURE 9. Humidity in air curtain over the boom distance graphic. 
The results presented in FIGURE 9 show that the relative humidity in the air curtain has no significant difference comparing the pipeline end distance. At the pipeline exit, all treatments with air humidification had significantly higher values than without humidification. At $250 \mathrm{~mm}$, only $0.16 \mathrm{~L} \mathrm{~min}^{-1}$ did not show significant value higher than the control. At $500 \mathrm{~mm}$, treatments with 1.92 and $0.48 \mathrm{~L} \mathrm{~min}^{-1}$ showed relative humidity in the air curtain significantly higher than control.

\section{CONCLUSIONS}

There was a reduction in temperature and increase in humidity in the air curtain of the boom sprayer when it was humidified.

\section{REFERENCES}

BALAN, M.G.; ABI SAAB, O. J. G.; SILVA, C.G.; RIO, A.; Deposição da calda pulverizada por três pontas de pulverização sob diferentes condições meteorológicas. Ciências Agrárias, Londrina, v. 29, n. 2, p. 293-298, abr./jun. 2008.

BAUER F. C.; RAETANO C. G. Assistência de ar na deposição e perdas de produtos fitossanitários em pulverizações na cultura da soja. Scientia Agrícola, Piracicaba, v. 57, n. 2, p. 271 - 276, abr./jun. 2000.

CHECHETTO, R. G.; ANTUNIASSI, U. R. Espectro de gotas gerado por diferentes adjuvantes e pontas de pulverização. Energia na Agricultura, Botucatu, v. 27, n. 3, p.130-142, jul./set. 2012,

CHRISTOVAM, R. S.; RAETANO, C. G.; AGUIAR JUNIOR, H. O.; DAL-POGETTO, M. H. F. A.; PRADO, E. P.; GIMENES, M. J.; KUNZ, V. L. Assistência de ar em barra de pulverização no controle da ferrugem asiática da soja. Bragantia, Campinas, v.69, n.1, p.231-238, 2010.

CUNHA, J. P. A. R. Simulação da deriva de agrotóxicos em diferentes condições de pulverização. Ciência e agrotecnologia, Lavras, v. 32, n. 5, p. 1616-1621, set./out. 2008.

FAGGION, F.; ANTUNIASSI, U. R. Desempenho de pontas de pulverização quanto a indução de ar nas gotas. Energia na Agricultura, Botucatu, v. 25, n. 4, p. 72-82, 2010.

MATTHEWS, G. A. Pesticide application methods. $2^{\text {nd }}$ ed. New York: Longman Scientific \& Technical, 1992.

NAVITSKI, P. M. Pesticide application by boom sprayer with double-sided air assistance of drops of a working liquid. 2010. Dissertation (Master) - Department of Agricultural Machines, The Belarussian State Agricultural Academy, Gorki, 2010.

PRADO, E. P.; RAETANO, C. G.; AGUIAR JUNIOR, H. O.; DAL-POGETTO, M. H. F. A.; CHRISTOVAM, R. S.; GIMENES, M. J.; ARAUJO, D. Velocidade do ar em barra de pulverização na deposição da calda fungicida, severidade da ferrugem asiática e produtividade da soja. Summa Phytopathology Botucatu, v. 36, n. 1, p. 45-50, 2010.

RAETANO, C. G. Assistência de ar em pulverizadores de barras: interferências e potencial de uso no sistema de plantio direto. In: ANTUNIASSI, U. R.; BOLLER, W. Tecnologia de aplicação para culturas anuais, Passo Fundo: Aldeia Norte; Fepaf, 2011. p. 105-119.

RAMOS, H. H.; PIO, L. C. Tecnologia de Aplicação de Produtos Fitossanitários. In: ZAMBOLIM, L.; CONCEIÇÃ̃, M. Z.; SANTIAGO, T. O que os engenheiros agrônomos devem saber para orientar o uso de produtos fitossanitários, 3. ed. rev. Viçosa: Ed. UFV, 2008. cap. 5, p. 155-224.

RAMSEY, R. J. L.; STEPHENSON, G. R.; HALL, J. C. A review of the effects of humidity, humectants, and surfactant composition on the absorption and efficacy of highly water-soluble herbicides. Pesticide Biochemistry and Physiology, San Diego, v. 82, p. 162-175, 2005. 
RAMSEY, R. J. L.; STEPHENSON, G. R.; HALL, J. C. Effect of humectants on the uptake and efficacy of glufosinate in wild oat (Avena fatua) plants and isolated cuticles under dry conditions. Weed Science, Champaign, v. 54, p. 205-211, Mar-Apr 2006.

RUEDELL, J. Tecnologia de aplicação de defensivos. Plantio Direto, Brasília, DF, v. 19, n. 6, p. 9$11,2002$.

XU, L.; ZHU, H.; OZKAN, H. E.; BAGLEY, W. E.; Krause, C. R.; Droplet evaporation and spread on waxy and hairy leaves associated with type and concentration of adjuvants. Pest Management Science, West Sussex, v. 7, n. 67, p.842-851, 2011.

YU, Y.; ZHU H.; FRANTZ, J. M.; RENDING, M. E.; CHNA, K. C.; OZKNA, H. E. Evaporation and coverage area of pesticide droplets on hairy and waxy leaves. Biosystems Engineering, London, v. 104, n. 3, p. 324-334, 2009. 